\title{
Knowledge, Practices and Use of Contact Lenses Among University Students in Turkey
}

\author{
Hamide Zengin ${ }^{1 *}$, Sinem Yalnızoğlu Çaka ${ }^{2}$, Elif Erbay Özdede ${ }^{1}$, İpek Tanır Tatar ${ }^{3}$, Nursan Çınar ${ }^{4}$
}

1. Bilecik Seyh Edebali University, Faculty of Health Sciences, Department of Pediatric Nursing, Bilecik, Turkey.

2. Kocaeli University, Faculty of Health Sciences, Department of Pediatric Nursing, Kocaeli, Turkey

3. Ministry of Health, Bafra Government Hospital, Clinic of Eye Diseases, Samsun, Turkey.

4. Sakarya University, Faculty of Health Sciences, Department of Pediatric Nursing, Sakarya, Turkey

*Corresponding Author: Hamide Zengin; E-mail: hamide.zengin@bilecik.edu.tr

\begin{abstract}
Aim

This study was conducted to determine the prevalence of contact lens (CL) use among university students, their awareness on CL, and CL users' practices for the cleaning and care of CLs.

Methods

The data of this cross-sectional study were collected between April 2019 and July 2019. The sample consisted of university students who volunteered to participate in the study. The data obtained from the study were evaluated by Statistical Package for the Social Science (SPSS) 22.0 package program in computer environment.

Results

929 students participated in the study and the average age of them was $21.99 \pm 1.85$ years (Min. 18 - Max. 24), and it was determined that $36.6 \%(n=340)$ of the participants were male, $10.2 \%(n=95)$ of the total were using CL, 91.6\% ( $n=87)$ of them used CL due to visual impairment. When students' levels of knowledge about the hygiene and care in CL use were examined $85.4 \%$ ( $\mathrm{n}=82$ ) washed their hands before wearing/removing CL, 85.3\% $(\mathrm{n}=81)$ cleaned the lens container and filled it with new solution when the solution in the container was reduced, $18.5 \%(\mathrm{n}=17)$ continued wearing CL while sleeping, $6.5 \%(\mathrm{n}=6)$ washed CL with tap water, and $28.3 \%$ $(n=26)$ of them stated that they swam in the sea with CL. It was determined that the prevalence of CL use was higher $(p=.045)$ among smoking students.
\end{abstract}

\section{Conclusion}

Health professionals are important in the trainings to be given to increase the students' knowledge of hygiene and care regarding the use of CL. More studies are needed on the effect of smoking status on CL use.

Keywords: CL use; Care; Knowledge; Prevalence; University students

\section{Introduction}

Contact lenses (CL) are small and less visible structures that are placed in the cornea and used to correct visual defects ${ }^{1}$. CLs can be used for therapeutic and cosmetic purposes as well as correcting myopia, hypermetropia and astigmatism. There are approximately 140 million CL users in the world and around 750,000 CL users in Turkey. ${ }^{1}$ While a study conducted in the United States (USA) showed that approximately one-third of CL users required doctor's check ${ }^{2}$, another study conducted in Japan showed that the prevalence of CL use was approximately $37.8 \%$ among high school students ${ }^{3}$.

CL-related problems may occur in each patient using CL. These problems are infections (most commonly bacterial, rarely fungal or amebic), allergic problems, long-term (without removal) use (corneal hypoxia and revascularization), toxicity (due to multi-purpose cleaning solutions or improper use of hydrogen peroxide solutions), and corneal erosion (often in rigid gas permeable CLs) ${ }^{4}$.

Young patients are more prone to inappropriate and longterm CL use. They may not change their lenses despite pain and redness ${ }^{4}$. Based on this information, this study was planned to determine the prevalence of CL wear among university students, their awareness on CL, and CL users' practices for the cleaning and care of CLs.

\section{Methods}

In this cross-sectional study, the population of the research consists of all students $(\mathrm{N}=49.955)$ continuing their education in a state university located in Sakarya province (a metropolitan city located in the north-west Turkey) in the 2018-2019 academic year. The data of the research were collected between April and July 2019.

After the sample formula for computation of the minimum sample size from the group with known population $[(\mathrm{n}=$ $\mathrm{Nz} z^{2} \mathrm{pq} /\left[\mathrm{d}^{2}(\mathrm{~N}-1)+\mathrm{z}^{2} \mathrm{pq}\right), \quad(\mathrm{n}=$ minimum sample size, $\mathrm{N}$ $=$ Population size, $\mathrm{z}=$ confidence level at 95\% (standard value of 1.96), $\mathrm{p}=$ guess for the expected proportion in the population, $\mathrm{q}=1.0-\mathrm{p}, \mathrm{d}=$ tolerable margin), $(\mathrm{N}=49.955$, $\mathrm{p}=0.5, \mathrm{q}=0.5, \mathrm{~d}=0.05, \mathrm{t}=1.96)]$, the minimum sample size was calculated as 382 at the confidence interval of $95 \%$ for number of individuals required to be included in the population $^{5}$. We assumed an attrition rate of $10 \%$, which 
corresponds to 38 participants, and thus the minimum sample size for the study was $382+38=420$. The minimum calculated sample size of 420 was obtained. However, a total of 1240 students were approached and 929 were included in the study (a response rate of $74.9 \%$ ). Of the students, 311 of 1240 were excluded from the study for various reasons (not accepting to participate in the study, incomplete filling in the data collection forms etc.). Despite the fact that the calculated minimum sample size for the study was 382, 929 students who gave consent were selected to increase the power of the study. The study sample comprised 929 students who accepted to participate in this study and matching the criteria. The students were selected randomly.

Inclusion criteria for the study were: a) Being a university student, b) Students' voluntariness to participate in the study, c) Having no communication problems, d) Being aged between 18-25 years.

The procedures of the study received ethics approval from the "Sakarya University Faculty of Medicine Ethics Committee" (Approval number: E.4529). A written approval was also obtained from the rectorate of the university to conduct the study in the university campus. After the participants were informed about the aim of the study, the confidentiality of the answers, and where and how the data would be used, the participants who volunteered and whose written consent was obtained were included in the sample.

The data were collected by using the questionnaire form consisting of questions about participants' descriptive characteristics and the use of CL obtained as a result of the literature review.

Questionnaire Form: It was prepared in Turkish language by the researchers as a result of the literature review and consisted of a total of 35 questions such as participants' age, gender, family type, perceived economic level, faculty, level of income, place of residence, smoking status, the questions measuring awareness on CL, CL wear, and CL's cleaning and care and side effects, and place of purchasing among CL wearers. The first version of the questionnaire form, which included the sociodemographic characteristics and the opinion/ practices of the participants about the use of CL, consisted of 42 questions. First of all, the pilot study of the questionnaire form was carried out with face-to-face interviews on 20 students ( $>18$ years and above), and the questionnaire was finalized with 35 questions by making some minor changes.

Collection of Data: After receiving the permissions of the rectorate and faculty deans, the questionnaires were distributed to students at the approved hours and collected in classrooms.

The data obtained from the study were evaluated by SPSS 22.0 package program in computer environment. Number, percentage, mean and standard deviation were used as descriptive statistics. In addition to the descriptive statistics, the Pearson Chi-square test was used to evaluate categorical variables. The results were evaluated at a confidence interval of $95 \%$ and the statistical significance (p) was evaluated at 0.05 .

\section{Results}

This study was conducted with 929 students who volunteered to participate in the study on the date of data collection. The students in medicine, dentistry, nursing and midwifery departments were not included in the sample by considering that it may affect the results of the study.
The average age of 929 students who participated in the study was 21.99 1.85 (range 18-25) years. When the sociodemographic characteristics of the participants were examined, it was determined that $340(63.4 \%)$ of them were female, $218(23.5 \%)$ of them were studying in the faculty of engineering, the perceived economic level of $670(72.1 \%)$ of them was income equivalent than expense, $729(78.5 \%)$ of them had a nuclear family type (a family consisting of two parents and their children), $352(37.9 \%)$ of them were staying in a dormitory, and $650(70 \%)$ of them were nonsmokers. It was determined that while $95(10.2 \%)$ of the students who participated in the study used CLs, 65 (68.4\%) of the participants using CL were female, $25(26.3 \%)$ of them were studying in the faculty of engineering, $38(40 \%)$ of them were staying in a dormitory, and $37(38.9 \%)$ of them were smokers.

Table 1 shows that when descriptive characteristics of the participants were compared by CL use, there was no statistically significant deference in prevalence of CL use between male and female students. Similar were reported with perceived economic level, family type, and place of residence $(p>0.05)$. However, there was statistically significant difference between CL use in smokers and nonsmokers. Accordingly, it was observed that the rate of CL use was higher in smokers $(\mathrm{p}=0.045)$.

When students' levels of knowledge about the hygiene and care of CL were examined in Table 2, $20(2.2 \%)$ of them stated that it would not be a problem to share CL, 75 (8.1\%) CL could be sold outside the optical shops, 16 (1.7\%) CL would not require the approvals of the Ministry of Health and FDA, $91(9.8 \%)$ it was legal to purchase CL without a prescription, and $204(22 \%)$ CL were used only for better vision purposes.

When the students' characteristics related to CL use were examined in Table 3, it was seen that $79(83.2 \%)$ used glasses before wearing CL, $46(48.9 \%)$ learned to wear/remove CL from an optician, $39(41.1 \%)$ wore CL for an average of 8-12 hours in a day, $55(57.9 \%)$ had been using CL for 2 years and above, $87(91.6 \%)$ used lenses due to visual impairment, 59 $(62.1 \%)$ purchased the brand recommended by the doctor while purchasing CL, $61(64.2 \%)$ price was important while purchasing CL, 77 (81.1\%) also had glasses at home while using CL, $84(88.4 \%)$ purchased CL with a prescription, $8(8.4 \%)$ increased the number of CL by themselves, 79 $(83.1 \%)$ purchased CL from the optician, 37 (39.4\%) had pain/stinging in the eye as a complication/side effect of CL, $65(71.4 \%)$ had pain and redness in their eyes during CL use and $61(64.2 \%)$ used glasses for a while in this case, 69 $(74.2 \%)$ went to doctor check in the recent year, $50 \%(n=46)$ were informed about the use of CL by an ophthalmologist, nurse, or optician in the recent year, and $93(97.3 \%)$ not shared their CL.

When students' levels of knowledge about the hygiene and care in CL use were examined in Table 4, 82 (85.4\%) washed their hands before wearing/removing CL, 81 (85.3\%) cleaned the lens container and filled it with new solution when the solution in the container was reduced, $17(18.5 \%)$ continued wearing CL while sleeping, $6(6.5 \%)$ washed CL with tap water, and $26(28.3 \%)$ of them stated that they swam in the sea with CL.

Table 5 shows that, there was no statistically significant deference in the development of complication related to CL use between male and female students. Similarly, no 
Table 1. Comparison of Descriptive Characteristics of the Participants with and without CL Use

\begin{tabular}{|c|c|c|c|}
\hline Variables & \begin{tabular}{|l|} 
Non-CL \\
users \\
$(n=834)$, \\
$n(\%)$
\end{tabular} & \begin{tabular}{|l} 
CL \\
Users \\
$(n=95)$, \\
$n(\%)$
\end{tabular} & $\mathrm{X}^{2} / \mathrm{p}$ value \\
\hline \multicolumn{4}{|l|}{ Gender } \\
\hline Female & $\begin{array}{l}524 \\
(62.8)\end{array}$ & $65(68.4)$ & \multirow[t]{2}{*}{$1.149 / 0.284$} \\
\hline Male & $\begin{array}{l}310 \\
(31.2)\end{array}$ & $30(31.6)$ & \\
\hline \multicolumn{4}{|l|}{ Faculty } \\
\hline Faculty of Engineering & $\begin{array}{l}193 \\
(23.1)\end{array}$ & 25 (26.3) & \multirow[t]{10}{*}{$11.473 / 0.24$} \\
\hline $\begin{array}{l}\text { Faculty of Political } \\
\text { Sciences }\end{array}$ & $\begin{array}{l}139 \\
(16.7) \\
\end{array}$ & $13(13.7)$ & \\
\hline $\begin{array}{l}\text { Faculty of Science and } \\
\text { Letters }\end{array}$ & $\begin{array}{l}134 \\
(16.1) \\
\end{array}$ & $14(14.7)$ & \\
\hline Faculty of Theology & $24(2.9)$ & $4(4.2)$ & \\
\hline $\begin{array}{l}\text { Faculty of Computer } \\
\text { and Information } \\
\text { Sciences }\end{array}$ & $18(2.2)$ & $3(3.2)$ & \\
\hline Faculty of Law & $\begin{array}{l}103 \\
(12.4)\end{array}$ & $17(17.9)$ & \\
\hline $\begin{array}{l}\text { Faculty of } \\
\text { Management }\end{array}$ & $25(3.0)$ & $6(6.3)$ & \\
\hline Faculty of Education & $34(4.1)$ & $1(1.1)$ & \\
\hline $\begin{array}{l}\text { Faculty of Art, Design } \\
\text { and Architecture }\end{array}$ & $76(9.1)$ & $4(4.2)$ & \\
\hline $\begin{array}{l}\text { Vocational School of } \\
\text { Health Services }\end{array}$ & $88(10.6)$ & $8(8.4)$ & \\
\hline \multicolumn{4}{|c|}{ Perceived Economic Level } \\
\hline $\begin{array}{l}\text { Income less than } \\
\text { expense }\end{array}$ & $\begin{array}{l}146 \\
(17.5)\end{array}$ & 15 (15.8) & \multirow[t]{3}{*}{$0.584 / 0.747$} \\
\hline $\begin{array}{l}\text { Income equivalent than } \\
\text { expense }\end{array}$ & \begin{tabular}{|l|}
602 \\
$(72.2)$
\end{tabular} & $68(71.6)$ & \\
\hline $\begin{array}{l}\text { Income more than } \\
\text { expense }\end{array}$ & $86(10.3)$ & $12(12.6)$ & \\
\hline \multicolumn{4}{|l|}{ Family Type } \\
\hline Nuclear family** & $\begin{array}{l}657 \\
(78.8) \\
\end{array}$ & $72(75.8)$ & \multirow[t]{3}{*}{$5.352 / 0.069$} \\
\hline Extended family*** & $\begin{array}{l}136 \\
(16.3) \\
\end{array}$ & $13(13.7)$ & \\
\hline Fragmented family ${ }^{* * * *}$ & $41(4.9)$ & $10(10.5)$ & \\
\hline \multicolumn{4}{|l|}{ Place of residence } \\
\hline At home with family & $\begin{array}{l}249 \\
(29.9)\end{array}$ & $27(28.4)$ & \multirow[t]{3}{*}{$0.205 / 0.902$} \\
\hline Dormitory & $\begin{array}{l}314 \\
(37.6)\end{array}$ & $38(40.0)$ & \\
\hline $\begin{array}{l}\text { At home with a } \\
\text { relative/friend }\end{array}$ & $\begin{array}{l}271 \\
(32.5)\end{array}$ & $30(31.6)$ & \\
\hline \multicolumn{4}{|l|}{ Smoking status } \\
\hline Smoking & $\begin{array}{l}242 \\
(29.0) \\
\end{array}$ & $37(38.9)$ & \multirow[t]{2}{*}{$4003 / 0.045^{\star}$} \\
\hline Not smoking & $\begin{array}{l}592 \\
(71.0)\end{array}$ & $58(61.1)$ & \\
\hline
\end{tabular}

$X^{2}=$ Chi-square test; $\quad{ }^{*} p<0.05$

${ }_{* *}$ Nuclear family: A family consisting of two parents and their children but not including aunts, uncles, grandparents, etc.

*** Extended family: A family unit that includes grandmothers, grandfathers, aunts, and uncles, etc. in addition to parents and children.

${ }^{* * * *}$ Fragmented family: Family broken up by parents' divorce or death. 
Table 2. Students' levels of knowledge about CL use

\begin{tabular}{|c|c|c|c|c|c|c|}
\hline \multirow[t]{2}{*}{ Statements $(N=929)$} & \multicolumn{2}{|c|}{ Right } & \multicolumn{2}{|c|}{ Wrong } & \multicolumn{2}{|c|}{ No knowledge } \\
\hline & $n$ & $\%$ & $n$ & $\%$ & $n$ & $\%$ \\
\hline CLs have a standard size and fits all. & 65 & 7.0 & 380 & 40.9 & 484 & 52.1 \\
\hline It is not a problem to share CLs. & 20 & 2.2 & 654 & 70.4 & 255 & 27.4 \\
\hline There is no risk of using $\mathrm{CL}$. & 52 & 5.6 & 439 & 47.3 & 438 & 47.1 \\
\hline CLs can be sold outside the optical shops. & 75 & 8.1 & 486 & 52.3 & 368 & 39.6 \\
\hline $\begin{array}{l}\text { CLs do not require the approvals of the Ministry of Health and } \\
\text { FDA. }\end{array}$ & 16 & 1.7 & 511 & 55.0 & 402 & 43.3 \\
\hline $\begin{array}{l}\text { Purchase of CLs without a prescription does not increase the risk } \\
\text { of permanent eye damage. }\end{array}$ & 41 & 4.4 & 504 & 54.3 & 384 & 41.3 \\
\hline It is legal to purchase CL without a prescription. & 91 & 9.8 & 370 & 39.8 & 468 & 50.4 \\
\hline CLs are used only for better vision purposes & 204 & 22.0 & 293 & 31.5 & 432 & 46.5 \\
\hline Parasites do not adhere to CLs and do not get in your eyes. & 39 & 4.2 & 333 & 35.8 & 557 & 60.0 \\
\hline
\end{tabular}

Table 3. Distribution of students' characteristics related to CL use

\begin{tabular}{|c|c|c|c|}
\hline Variables $(n=95)$ & & $n$ & $\%$ \\
\hline \multirow{2}{*}{$\begin{array}{l}\text { Glasses-wearing status before wearing } \\
\text { CL }\end{array}$} & Yes & 79 & 83.2 \\
\hline & No & 16 & 16.8 \\
\hline \multirow{3}{*}{$\begin{array}{l}\text { From whom wearing/removing } C L \text { is } \\
\text { learned }\end{array}$} & Optician & 46 & 48.9 \\
\hline & On their own & 40 & 42.6 \\
\hline & From healthcare personnel & 8 & 8.5 \\
\hline \multirow[t]{4}{*}{ Daily duration of wearing $\mathrm{CL}$} & Less than 8 hours & 13 & 13.7 \\
\hline & $8-12$ hours & 39 & 41.1 \\
\hline & 13-16 hours & 23 & 24.2 \\
\hline & More than 16 hours & 20 & 21.1 \\
\hline \multirow[t]{4}{*}{ Duration of using $\mathrm{CL}$} & Less than 6 months & 11 & 11.6 \\
\hline & 6-12 months & 11 & 11.6 \\
\hline & $1-2$ years & 18 & 18.9 \\
\hline & 2 years and more & 55 & 57.9 \\
\hline \multirow[t]{2}{*}{ Reason for wearing $\mathrm{CL}$} & Visual impairment & 87 & 91.6 \\
\hline & Aesthetic & 8 & 8.4 \\
\hline \multirow{2}{*}{$\begin{array}{l}\text { Would you purchase the brand } \\
\text { recommended by the doctor while } \\
\text { purchasing CL? }\end{array}$} & Yes & 59 & 62.1 \\
\hline & No & 36 & 37.9 \\
\hline \multirow{2}{*}{$\begin{array}{l}\text { Is price important to you while } \\
\text { purchasing CL? }\end{array}$} & Yes & 61 & 64.2 \\
\hline & No & 34 & 35.8 \\
\hline \multirow{2}{*}{$\begin{array}{l}\text { Do you have glasses to use with } \mathrm{CL} \text { at } \\
\text { home? }\end{array}$} & Yes & 77 & 81.1 \\
\hline & No & 18 & 18.9 \\
\hline
\end{tabular}


Table 3 Cont....

\begin{tabular}{|c|c|c|c|}
\hline \multirow{2}{*}{$\begin{array}{l}\text { Do you purchase CLs with a } \\
\text { prescription? }\end{array}$} & Yes & 84 & 88.4 \\
\hline & No & 11 & 11.6 \\
\hline \multirow{2}{*}{$\begin{array}{l}\text { Have you ever increased the number of } \\
\text { CL by yourself? }\end{array}$} & Yes & 8 & 8.4 \\
\hline & No & 87 & 91.6 \\
\hline \multirow[t]{4}{*}{ Where do you purchase $\mathrm{CL}$ ? } & From optical shop & 79 & 83.1 \\
\hline & From the internet & 13 & 13.7 \\
\hline & From the doctor & 2 & 2.1 \\
\hline & From the hospital & 1 & 1.1 \\
\hline \multirow{5}{*}{$\begin{array}{l}\text { What are the side effects/complications } \\
\text { due to CL use? (Multiple options are } \\
\text { marked) }\end{array}$} & Eye pain/eye stinging & 37 & 39.4 \\
\hline & Hypersensitivity to light & 11 & 11.7 \\
\hline & Red, swollen eyes & 13 & 13.8 \\
\hline & Itchy watery eyes & 17 & 18.1 \\
\hline & $\begin{array}{l}\text { Other (Vision problem, Blindness, Corneal scratches/ } \\
\text { abrasions, Conjunctivitis (pink eye), Corneal ulcer) }\end{array}$ & 8 & 8.6 \\
\hline \multirow[t]{3}{*}{ Type of CL used } & $\begin{array}{l}\text { Daily (disposable) } \\
\text { Lenses }\end{array}$ & 4 & 4.2 \\
\hline & Monthly Lenses & 85 & 89.5 \\
\hline & Annual Lenses & 6 & 6.3 \\
\hline \multirow{2}{*}{$\begin{array}{l}\text { Pain or redness in the eyes while using } \\
\text { contact lenses }\end{array}$} & Yes & 65 & 71.4 \\
\hline & No & 26 & 28.6 \\
\hline \multirow{3}{*}{$\begin{array}{l}\text { What do you do when you have pain } \\
\text { and redness in your eyes? (Multiple } \\
\text { options are marked) }\end{array}$} & I continue to use my lens & 8 & 8.4 \\
\hline & I remove my lens and use glasses for a while & 61 & 64.2 \\
\hline & I consult my doctor & 30 & 31.6 \\
\hline \multirow{2}{*}{$\begin{array}{l}\text { Have you gone to an ophthalmologist in } \\
\text { the recent year? }\end{array}$} & Yes & 69 & 74.2 \\
\hline & No & 24 & 25.8 \\
\hline \multirow{2}{*}{$\begin{array}{l}\text { Has your ophthalmologist, nurse, or } \\
\text { optician informed you about the use of } \\
C L \text { in the recent year? }\end{array}$} & Yes & 46 & 50.0 \\
\hline & No & 46 & 50.0 \\
\hline \multirow{2}{*}{$\begin{array}{l}\text { Do you share your CL or use someone } \\
\text { else's CL? }\end{array}$} & Yes & 2 & 2.1 \\
\hline & No & 93 & 97.9 \\
\hline
\end{tabular}

Table 4. Students' levels of knowledge about the hygiene and care in CL use

\begin{tabular}{|l|l|l|l|l|l|l|}
\hline \multirow{2}{*}{ Practices } & \multicolumn{2}{l}{ Yes } & \multicolumn{2}{l}{ Sometimes } & \multicolumn{2}{l}{ No } \\
\cline { 2 - 7 } & $\mathrm{n}$ & $\%$ & $\mathrm{n}$ & $\%$ & $\mathrm{n}$ & $\%$ \\
\hline $\begin{array}{l}\text { I wash my hands before wearing/ } \\
\text { removing CLs }\end{array}$ & 82 & 85.4 & 14 & 14.6 & 0 & 0 \\
\hline $\begin{array}{l}\text { When the solution in the container is } \\
\text { reduced, I clean the lens container } \\
\text { and fill it with a new solution. }\end{array}$ & 81 & 85.3 & 14 & 14.7 & 0 & 0 \\
\hline $\begin{array}{l}\text { When the solution in the lens container } \\
\text { is reduced, I add new solution to it. }\end{array}$ & 42 & 44.7 & 28 & 29.8 & 24 & 25.5 \\
\hline I do my eye care after removing CL & 35 & 37.2 & 39 & 41.5 & 20 & 21.3 \\
\hline I change CL when it expires & 69 & 72.6 & 22 & 23.2 & 4 & 4.2 \\
\hline I continue wearing CL while sleeping & 17 & 18.5 & 25 & 27.2 & 50 & 54.3 \\
\hline $\begin{array}{l}\text { I wear CL while swimming or having } \\
\text { bath/shower }\end{array}$ & 24 & 25.5 & 30 & 31.9 & 40 & 42.6 \\
\hline I swim at sea with CL & 26 & 28.3 & 13 & 14.1 & 53 & 57.6 \\
\hline I wash my CL with tap water & 6 & 6.5 & 3 & 3.2 & 84 & 90.3 \\
\hline $\begin{array}{l}\text { I swim in a lake or stream with CL in } \\
\text { my eyes }\end{array}$ & 21 & 22.6 & 6 & 6.5 & 66 & 71.0 \\
\hline
\end{tabular}


Table 5. Comparison of the groups between the development complications due to $\mathrm{CL}$ use according to some variables

\begin{tabular}{|c|c|c|c|}
\hline \multirow[t]{2}{*}{ Characteristics ( $n=95)$} & \multicolumn{2}{|c|}{$\begin{array}{l}\text { Development of complications } \\
\text { due to }\end{array}$} & \multirow{2}{*}{\begin{tabular}{|l|} 
Total \\
$\mathrm{n}(\%)$ \\
\end{tabular}} \\
\hline & Yes n (\%) & Non $(\%)$ & \\
\hline \multicolumn{4}{|l|}{ Gender } \\
\hline Female & $29(70.7)$ & $35(66.0)$ & $64(68.1)$ \\
\hline Male & $12(29.3)$ & $18(34.0)$ & $30(31.9)$ \\
\hline$x^{2}=0.234 \quad p=0.628$ & & & \\
\hline \multicolumn{4}{|l|}{ Perceived economic level } \\
\hline Good & $6(14.6)$ & $9(17.0)$ & $15(16.0)$ \\
\hline Moderate & $31(75.6)$ & $36(67.9)$ & $67(71.3)$ \\
\hline Bad & $4(9.8)$ & $8(15.1)$ & $12(12.8)$ \\
\hline$X^{2}=0.787 \quad p=0.675$ & & & \\
\hline \multicolumn{4}{|l|}{ Student's place of residence } \\
\hline At home with family & $12(29.3)$ & $14(26.4)$ & $26(27.7)$ \\
\hline Dormitory & $15(36.6)$ & $23(43.4)$ & $38(40.4)$ \\
\hline At home with a relative or friend & $14(34.1)$ & $16(30.2)$ & $30(31.9)$ \\
\hline$x^{2}=0.447 \quad p=0.800$ & & & \\
\hline \multicolumn{4}{|l|}{ Smoking status } \\
\hline Smoking & $15(36.6)$ & $21(39.6)$ & $36(38.3)$ \\
\hline Not smoking & $26(63.4)$ & $32(60.4)$ & $58(61.7)$ \\
\hline$X^{2}=0.090 \quad p=0.832$ & & & \\
\hline \multicolumn{4}{|l|}{ Use of $C L$ while sleeping } \\
\hline Generally & $6(15.0)$ & $11(21.2)$ & $17(18.5)$ \\
\hline Rarely & $9(22.5)$ & $16(30.8)$ & $25(27.2)$ \\
\hline Never & $25(62.5)$ & $25(48.1)$ & $50(54.3)$ \\
\hline$X^{2}=1.898 \quad p=0.387$ & & & \\
\hline \multicolumn{4}{|c|}{ Use of $C L$ while swimming or having bath/shower } \\
\hline Yes & $29(41.4)$ & $41(58.6)$ & $70(74.5)$ \\
\hline No & $12(50.0)$ & $12(50.0)$ & $24(25.5)$ \\
\hline$X^{2}$ Test $=0.534 \quad p=0.465$ & & & \\
\hline
\end{tabular}

$X^{2}=$ Chi-square test; $\quad \quad{ }^{*} p<0.05$

significant deference was found with perceived economic level, place of residence, smoking status, using CL while sleeping/ swimming/ bathing/showering, and development of complication $(\mathrm{p}>0.05)$.

\section{Discussion}

In this study conducted to determine university students' awareness on CL, the prevalence of CL wear, and CL users' practices for the cleaning and care of CLs, it was determined that $10.2 \%$ of the students used CL and that $68.4 \%$ of the participants using CL were female. While this prevalence was reported to be 5.01\% in Australia ${ }^{6}$ which is low compared to the prevalence in this study, it was found to be $9 \%$ in Singapore ${ }^{7}$ which is similar to this study, and it was found to be $14 \%$ in Malaysia ${ }^{8}$ and USA ${ }^{9}$ which is higher than this study. Another study found the prevalence of current and previous CL users to be $15.1 \%$ and 32.5\% (Alzahrani 2021), which are higher than this study. According to the results of the study conducted by Qiurong Zhu et al., (2018) with the participation of 1500 university students in Chengdu, the prevalence of CL wear was reported to be $19.8 \%$ among females which is higher than this study result ${ }^{11}$. In the same study, the prevalence of CL wear was found to be $82.15 \%{ }^{11}$ in female gender and $83 \%{ }^{9}, 59.2 \%{ }^{12}$ in other studies, which are similar to this study. In this study, the prevalence of CL use was found to be higher among smokers $(p=0.045)$. Similarly, in the study of Berenson et al. (2019), it was determined that the use of CL was higher among smoking students $(p=0.008)$, which is similar to this study ${ }^{9}$. The damages of smoking on all systems have been proven. The tar and nicotine accumulated in the smoker's fingers can contaminate the CLs while wearing/removing lenses, which may also endanger eye health by causing burning sensation in the eyes. There is need to create awareness among students who wear CLs to stop smoking.

In this study, the view that CLs do not have a standard size $(40.9 \%)$ was found to be common. In a study conducted in the USA, the view that CLs have a standard size was common by more than $70 \%{ }^{9}$, which is not similar to this study. In Turkey, prescription is compulsory when CLs are intended to be purchased from a pharmacy or optician, these 
prescriptions are valid for one year. However, CLs are also sold on the internet, and in this case, the requirement of prescription is eliminated. While $52.3 \%$ of the students who participated in this study indicated that CLs should not be sold outside the opticians, $55 \%$ of them indicated that CLs should be sold with the approvals of the Ministry of Health and FDA, and $39.8 \%$ of them indicated that it was not legal to purchase CL without a prescription. The purchase of $\mathrm{CL}$ without a prescription does not constitute a crime in the USA ${ }^{13}$. In the People's Republic of China, there is no requirement of prescription for CL sales and CLs can also be sold outside the optician ${ }^{11}$.

In the study, while $48.9 \%$ of the students using CL stated that they learned to wear/remove CL from the optician, $91.6 \%$ of them stated that they wore CL due to visual impairment. In a study, $55.5 \%$ of the CL users reported getting the information from ophthalmologists ${ }^{14}$. In the studies, the prevalence of CL wearers for aesthetic purposes were reported to be $57.91 \%{ }^{11}, 58.3 \%{ }^{15}$ which is not similar to this study.

In this study, it was reported that while $89.5 \%$ of the students using CL used monthly lenses, $57.9 \%$ of CL wearers reported that they wore CL for more than 2 years. While the prevalence of monthly use of disposable lens was found to be $72 \%$ among the students studying in the faculty of medicine in Malaysia ${ }^{8}$, it was found to be $47 \%$ in Brazil ${ }^{16}$. Similarly, the other studies in the study of Qiurong Zhu et al. (2018), the prevalence of monthly use of disposable lens was found to be $43.75 \%{ }^{11}, 63.8 \%{ }^{17}$. These results are similar to this study.

In this study, $41.1 \%$ of the students using CL reported that they wore CL between 8-12 hours in a day. In another study, it was reported that $54.21 \%$ of CL wearers wore CL between 6-12 hours in a day ${ }^{13}$. In the cross-sectional observational case series conducted by Reiko Arita et al. (2009), 121 eyes of 121 patients with CL use and 137 eyes of 137 patients without CL use as a control group were included in the study ${ }^{18}$. The tear break-up time in patients was recorded by examining the Schirmer's test, meibomian gland changes (Meiboscore), and the stability of tear film. Meiboscore was found to be significantly higher in CL users compared to the control group ${ }^{18}$. It was observed that meiboscore increased as the duration of using CL increased. Meibomian glands are responsible for lipid secretion and plays an important role in creating surface tension ${ }^{19}$.

In this study, it was reported that while $39.4 \%$ of them described eye pain/eye stinging as a complication of CL, and $71.4 \%$ of them had pain and redness in their eyes during CL use. In a study, dry eye, allergic conjunctivitis and corneal erosion were determined as the complications of $\mathrm{CL}^{20}$. In a study conducted in the USA, it was reported that $39.6 \%$ of CL users had eye pain, $47.2 \%$ of them had itching and watering of eyes, and $18.9 \%$ of them had redness and swelling in the eyes ${ }^{9}$. Şengör et al. (2018) reported that the most common complaints of CL users were dry eye and discomfort in the evening ${ }^{14}$. The lipid layer in front of the lens is thinner among CL users compared to non-CL users, In CL users with dry eye complaints (burning, stinging, foreign body sensation in the eye, pain, ${ }^{21}$ tear thinning time in front of the lens is directly proportional to the severity of dry eye. It is considered that the increase in tear evaporation rate is not caused by the impairment of lipid release from the meibomian glands, but by the change in the lipid composition. In CL users, a decrease in contrast sensitivity is observed due to the rapid thinning and breaking of the tear in front of the lens ${ }^{22}$.

In this study, $85.3 \%$ of the students (who use CLs) washed hands before wearing/removing CLs. In studies conducted in the UK and Germany ${ }^{23}$, it was reported that the proportion of students who were washing hands after removing their CL was $62 \%$ and $53 \%$ respectively. Those who washed hands before wearing CL was $77 \%$ and $72 \%$ respectively. Hand hygiene was found to be $11 \%$ among CL users in Australia ${ }^{24}$. In another study, the prevalence of washing hands while wearing CL was reported to be $86.20 \%{ }^{11}$. Bacterial and fungal keratitis development due to poor hand hygiene are known complications in CL users. However, not only bacterial and fungal agents, but also viral pathogens are transmitted through poor hand hygiene, which is especially important in this period during which the SARS-CoV-2 pandemic is being experienced.

In this study, the ratio of those who gave the answer "When the solution in the container is reduced, I clean the lens container and fill it with a new solution" was found to be $85.3 \%$. This ratio was found to be $64.64 \%$ in a study conducted in the People's Republic of China ${ }^{11}$. As a result of insufficient cleaning of CL containers, permanent microbial contamination is common and associated with microbial keratitis and sterile corneal infiltration ${ }^{25}$. The result of this study indicated that it also decreased the risk of microbial contamination.

In this study, the ratio of those who continued to wear CL while sleeping was found to be between $18.5-27.2 \%$. In a study, this ratio was found to be approximately $30 \% .{ }^{11}$ Sleeping by wearing CL poses a risk for microbial keratitis ${ }^{26,}$ 27 and corneal infiltration 27,28 .

In this study, it was determined that male students had more pain and redness due to CL use compared to female students $(p=.024)$. Burning in the eyes, stinging, foreign body sensation, and pain are the conditions that mostly affect females, one of the reasons of which is the low androgen, high estrogen level in serum. Low levels of androgen and high levels of estrogen in serum are risk factors for dry eye. ${ }^{29,30}$ Our result is incompatible with the literature. It is recommended to conduct relevant large-scale studies.

\section{Limitations}

The survey is included only university students in Sakarya, which may not be represent of the whole community. More comprehensive, multicenter studies could be done.

\section{Conclusion}

It was observed that the students using CLs obtained knowledge about the care and hygiene of CLs from reliable sources at a very low level. There is need to create awareness among students who wear CLs to stop smoking that healthcare professionals should provide more training on the care and use of CLs, and that the sales of CLs over the internet without a prescription should be prevented.

\section{Conflict of Interest}

The authors declared no conflicts of interest.

\section{Acknowledgements}

We would like to thank Sakarya University and its students who participated in the study. This research did not receive any specific grant from funding agencies in the public, 
commercial, or not-for-profit sectors.

\section{References}

1.Uçakhan Gündüz Ö, Baş Z. Kontakt Lens Kullanımı ile İlişkili Kuru Göz. MN Oftalmoloji. 2016;23(Suppl 1):83-90.

2.Cope JR, Collier SA, Rao MM, et al. Contact Lens Wearer Demographics and Risk Behaviors for Contact Lens-Related Eye Infections--United States, 2014. MMWR Morb Mortal Wkly Rep. 2015;64(32):865-870. doi:10.15585/mmwr.mm6432a2.

3.Uchino M, Dogru M, Uchino Y, et al. Japan Ministry of Health study on prevalence of dry eye disease among Japanese high school students. Am J Ophthalmol. 2008;146(6):925-29. https://doi.org/10.1016/j. ajo.2008.06.030.

4.Levinson B. (Çev: Halili E.; Editors: Maguire J.I., Murchison A.P, Jaeger E.A. Çev. Ed.: Bozkurt T.K). Kontakt Lens Komplikasyonları (In: Wills Eye Enstitüsü 5- Dakikada Göz Hastalıklarının Değerlendirilmesi), Ankara: Güneş Tıp Kitabevleri; 2015, p. 214-5.

5.Büyüköztürk Ş, Çakmak EK, Akgün ÖE, Karadeniz Ş, Demirel F. Bilimsel Araştırma Yöntemleri. 16th ed. Ankara: Pegem Akademi; 2014.

6.Edwards K, Keay L, Naduvilath T, Stapleton F. The penetrance and characteristics of contact lens wear in Australia. Clin Exp Optom. 2014;97(1):48-54. DOI:10.1111/cxo.12078.

7.Lee YC, Lim CW, Saw SM, Koh D. The prevalence and pattern of contact lens use in a Singapore community. The CLAO J. 2000 Jan;26(1):21-25. PMID: 10656305.

8.Tajunisah I, Reddy SC, Phuah SJ. Knowledge and practice of contact lens wear and care among medical students of University of Malaya. Med J Malaysia. 2008;63(3):207-10.

9.Berenson AB, Chang M, Hirth JM, Merkley KH. Use and misuse of cosmetic contact lenses among US adolescents in Southeast Texas. Adolesc Health Med Ther. 2019;10:1-6. doi:10.2147/AHMT.S196573.

10.Alzahrani O, Alshehri FA, Alali AO, et al. Contact Lens Practices and Knowledge of Complications and its Association with Refractive Error in Saudi Arabia. Cureus. 2021;13(1):e12786. doi:10.7759/ cureus. 12786 .

11.Zhu Q, Yang B, Deng N, et al. The use of contact lenses among university students in Chengdu: Knowledge and practice of contact lens wearers. Cont Lens Anterior Eye. 2018 Apr;41(2):229-33. https://doi. org/10.1016/j.clae.2017.12.008.

12.Konne NM, Collier SA, Spangler J, Cope JR. Healthy Contact Lens Behaviors Communicated by Eye Care Providers and Recalled by Patients - United States, 2018 [published correction appears in MMWR Morb Mortal Wkly Rep. 2019 Sep 20;68(37):809]. MMWR Morb Mortal Wkly Rep. 2019;68(32):693-7. doi:10.15585/mmwr. mm6832a2.

13.Steinemann TL, Fletcher M, Bonny AE, et al. Over-the-counter decorative contact lenses: cosmetic or medical devices? A case series. Eye Contact Lens. 2005;31(5):194-200. DOI: 10.1097/01. icl.0000175654.79591.03.

14.Şengör T, Alkibay S, Ermeç Sertoğlu A, Aydın Kurna S. Survey to Determine Perceptions and Practices in Contact Lens Use and Identify Key Features of Safe Use Education. Turk J Ophthalmol. 2018;48(6):288-294. doi:10.4274/tjo.60465.

15.Alobaidan OS, Alkhalifah MK, AlSayegh AA, et al. Knowledge and practice regarding contact lens among Saudi urban contact lens users. Saudi J Ophthalmol. 2018 Apr-Jun;32(2):93-96. doi: 10.1016/j. sjopt.2017.09.008.

16.Vidotti VG, Kamegasawa A. Profile of medical students from the Universidade Estadual Paulista-UNESP-Botucatu, who wear contact lenses. Arq Bras de Oftalmol. 2006;69(2):197-201. https://doi. org/10.1590/S0004-27492006000200012.

17.Khoza N, Moodley T, Sokhulu S, et al. Knowledge, attitudes and practices of contact lens use in a South African adolescent population. Afri Health Sci. 2020 Jun;20(2):768-774. doi: 10.4314/ahs.v20i2.29.

18.Arita R, Itoh K, Inoue K, Kuchiba A, Yamaguchi T, Amano S. Contact Lens Wear Is Associated with Decrease of Meibomian Glands. Ophthalmology. 2009;116(3):379-84. https://doi.org/10.1016/j. ophtha.2008.10.012.

19.Selver ÖB, Palamar M, Menteş J, Yağcı A. Impact of contact lens wear on ocular surface and Meibomian glands. Ege Journal of Medicine / Ege Tıp Dergisi. 2018;57(4):191-4.

20.Yazar E, Alaçayır F, Altınok AA, Serdar K, Özturk F. Keratokonuslu Hastalarda Gaz Geçirgen Sert Kontakt Lens Uygulama Sonuçlarımız. Turk J Ophthalmol. 2013;43:432-6. DOI: 10.4274/tjo.90377.

21.Salib GM, McDonald MB, Smolek M. Safety and efficacy of cyclosporine $0.05 \%$ drops versus unpreserved artificial tears in dry-eye patients having laser in situ keratomileusis. J Cataract Refract Surg. 2006;32(5):772-8. https://doi.org/10.1016/j.jcrs.2005.10.034.

22.Nichols JJ, Sinnott LT. Tear film, contact lens, and patient-related factors associated with contact lens-related dry eye. Invest Ophthalmol Vis Sci. 2006;47(4):1319-28. doi:https://doi.org/10.1167/iovs.05-1392.

23.Bowden T, Nosch DS, Harknett T. Contact lens profile: a tale of two countries. Cont Lens Anterior Eye. 2009 Dec;32(6):273-82. https://doi. org/10.1016/j.clae.2009.09.002.

24.Wu Y, Carnt N, Stapleton F. Contact lens user profile, attitudes and level of compliance to lens care. Cont Lens Anterior Eye. 2010 Aug;33(4):183-8. https://doi.org/10.1016/j.clae.2010.02.002.

25.Vijay AK, Willcox M, Zhu H, Stapleton F. Contact Lens Storage Case Hygiene Practice and Storage Case Contamination. Eye Contact Lens. 2015;41(2):91-7. doi: 10.1097/ICL.0000000000000070.

26.Stapleton F, Keay L, Edwards K, et al. The incidence of contact lens-related microbial keratitis in Australia. Ophthalmology. 2008;115(10):1655-62. https://doi.org/10.1016/j.ophtha.2008.04.002.

27.Hickson-Curran S, Chalmersb RL, Rileyaet C. Patient attitudes and behavior regarding hygiene and replacement of soft contact lenses and storage cases. Cont Lens Anterior Eye. 2011 Oct;34(5):207-15. https:// doi.org/10.1016/j.clae.2010.12.005.

28.Szczotka-Flynn L, Diaz M. Risk of corneal inflammatory events with silicone hydrogel and low dk hydrogel extended contact lens wear: a meta-analysis. Optom Vis Sci. 2007;84(4):247-56. doi: 10.1097/ OPX.0b013e3180421c47.

29. Sullivan DA. Sex and sex steroid influences on the dry eye syndrome. In: Pflugfelder SC, Beuerman RW, Stern ME Editors. Dry eye and ocular surface disorders. New York, Marcel Dekker, 2004.

30.Valtysdttir ST, Wide L, Ha"llgren R. Low serum dehydroepiandrosterone sulfate in women with primary Sjogren's syndrome as an isolated sign of impaired HPA axis function. J Rheumatol. 2001;28:1259-65. 